\title{
RUSSIA'S REAL SECTOR OF THE ECONOMY IN JANUARY 2016: FACTORS AND TRENDS
}

\author{
O.Izryadnova
}

In January 2016, retail trade turnover decline by $7.3 \%$ and fall of investments in fixed capital by $8.4 \%$ have significantly affected domestic market. Dynamic of consumer market was determined to simultaneous decrease of demand on food products by $6.3 \%$ and on non-food products by $7.2 \%$ in comparison with 2015. In January 2015, the market of investment goods and services was characterized by contraction of works in construction by $4.2 \%$ per annum. Industrial production in January of the current year against January 2015 in annual terms constituted $97.3 \%$, meanwhile the extraction of natural resources saw growth by $0.4 \%$ and the manufacturing industry registered decline of output by 5.6\%. Total number of jobless against January 2015 went up by $6.2 \%$ and of the officially registered ones by $10.1 \%$.

Deterioration of the economic situation in January 2016 was rather foreseen and was determined by trends and factors effective since H2 2014.

In 2014-2015, sharp changes in geopolitical situation have enhanced negative impact of domestic development constraints. At year-end 2015, GDP constituted $96.3 \%$ against the indicator of the previous year and declined for the first time since 2008-2009 crisis. Unstable dynamic of external demand piled on the pressure on the pattern of economic development. Although on the whole throughout 2015, movement of export and net export remained positive. However, this has not offset a sharp decline of consumer and investment demand and contraction of industrial production. The fall of domestic demand in the course of recent eight months had a negative impact on

Table 1

MAIN MACROECONOMIC INDICATORS OF SOCIO-ECONOMIC DEVELOPMENT IN 2011-2016, \% TO PREVIOUS YEAR

\begin{tabular}{|l|c|c|c|c|c|c|}
\hline & 2011 & 2012 & 2013 & 2014 & 2015 & $\begin{array}{c}\text { January } 2016 \\
\text { to January } \\
2015\end{array}$ \\
\hline GDP & 104.3 & 103.5 & 101.3 & 100.7 & 96.3 & \\
\hline Industrial production index & 105 & 103.4 & 100.4 & 101.7 & 96.6 & 97.3 \\
\hline Extraction of natural resources & 101.8 & 101 & 101.1 & 101.4 & 100.3 & 100.4 \\
\hline Manufacturing & 108 & 105.1 & 100.5 & 102.1 & 94.6 & 94.4 \\
\hline Agricultural products & 123.0 & 95.2 & 105.8 & 103.7 & 103.0 & 102.5 \\
\hline $\begin{array}{l}\text { Volume of works in construction } \\
\text { Investment in capital goods }\end{array}$ & 105.1 & 102.5 & 100.1 & 97.7 & 93.0 & 95.8 \\
\hline Retail trade turnover & 110.8 & 106.8 & 100.8 & 97.3 & 91.6 & 91.6 \\
\hline $\begin{array}{l}\text { Volume of paid services } \\
\text { to population }\end{array}$ & 107.1 & 106.3 & 103.9 & 102.5 & 90.0 & 92.7 \\
\hline $\begin{array}{l}\text { Real disposable money } \\
\text { income of population }\end{array}$ & 100.5 & 103.7 & 102.0 & 101.3 & 97.9 & 97.3 \\
\hline Accrued wages & 102.8 & 108.4 & 104.8 & 101.2 & 90.5 & 93.9 \\
\hline
\end{tabular}

Source: Rosstat. 
macroeconomic indicators. Contraction of real income of population amid drastic depreciation of the ruble and surge of inflation have led to a wide scale reduction of consumer demand, shrinkage of retail trade turnover and decline of individual lending activity.

High share of import observed in retail trade turnover as well as in the volume of intermediate consumption and in investment in capital assets has strengthened dependence of gross economic resources balance from the changes of foreign economic condition. Import pattern was changing under the effect of a more profound fall of supplies of consumer and capital goods against intermediate consumption goods. It should be noted that reduction of the share of consumer goods in import pattern is explained both by import substitution $^{1}$ of food products and by general reduction of people's demand amid higher-thananticipated price growth on import compared to domestic

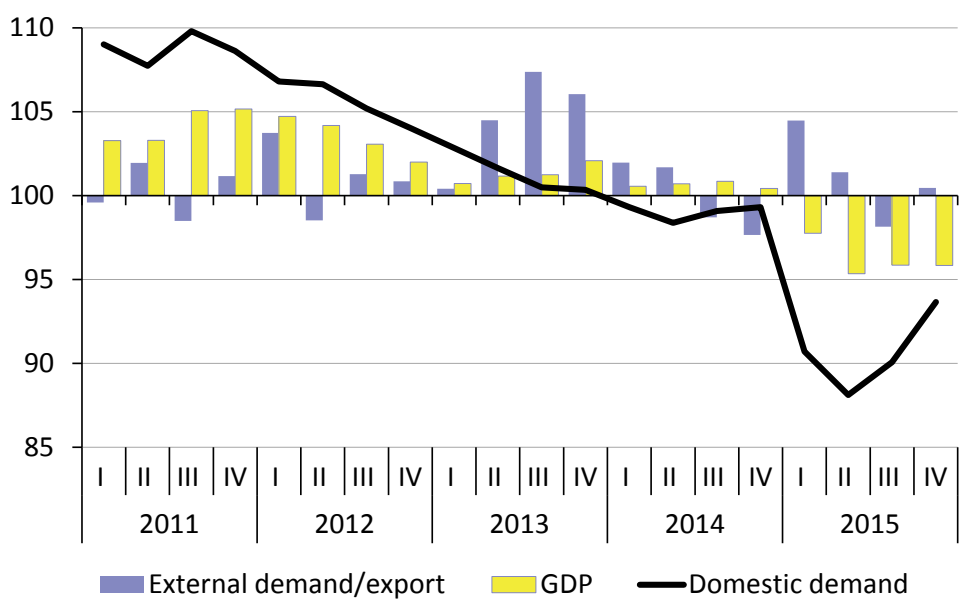

Source: Rosstat.

Fig. 1. Movement of GDP along components of domestic and external demand in 2011-2015, \% to corresponding period of previous year

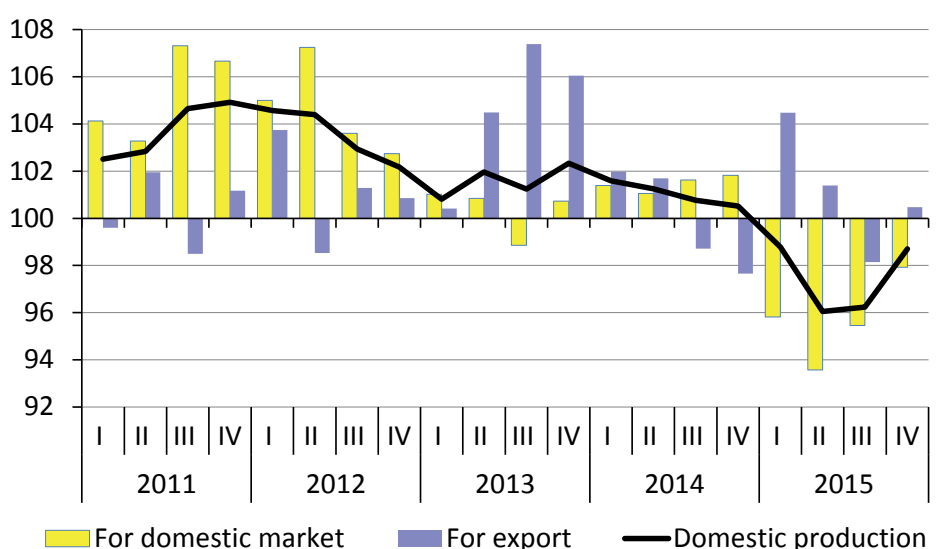

Source: Rosstat.

Fig. 2. Movement of domestic production of goods and services across components in 2011-2015, \% to corresponding quarter of previous year products.

In 2014-2015, decrease of investment in capital assets has led to simultaneous contraction of demand on domestic and imported capital goods and aggravated the development of negative trends on the domestic market. Additional difficulties have popped up due to restrictions on supply of certain types of equipment required for the implementation of investment plans of extracting and manufacturing industries and for the infrastructure projects.

Main indicators of the domestic market were determined by a correlation of growth rates of domestic production for internal consumption and external market, on the one hand, and dynamic and import pattern, on the other.

Slowdown of the domestic production was conditioned both by low competitiveness of domestic products and services against imported analogues and by low efficiency of production in the segment of non-tradable goods and services compared to export oriented sector of the economy. In 2015,

1 As detailed in article by Georgy Idrisov "Industrial Transformation Amid Deterioration of Trade Conditions" released in this issue. 
contraction by $6.2 \%$ of production goods and services for domestic consumption, which was not offset by growth of export have resulted in the intensification of production slump to $3.6 \%$ against last year. Simultaneous decrease of output both in tradable and non-tradable sectors of the economy in 2015 was registered for the first time since 2009. Decline of production of gross value added in non-tradable sector of the economy by $3.7 \%$ in comparison with last year was determined by

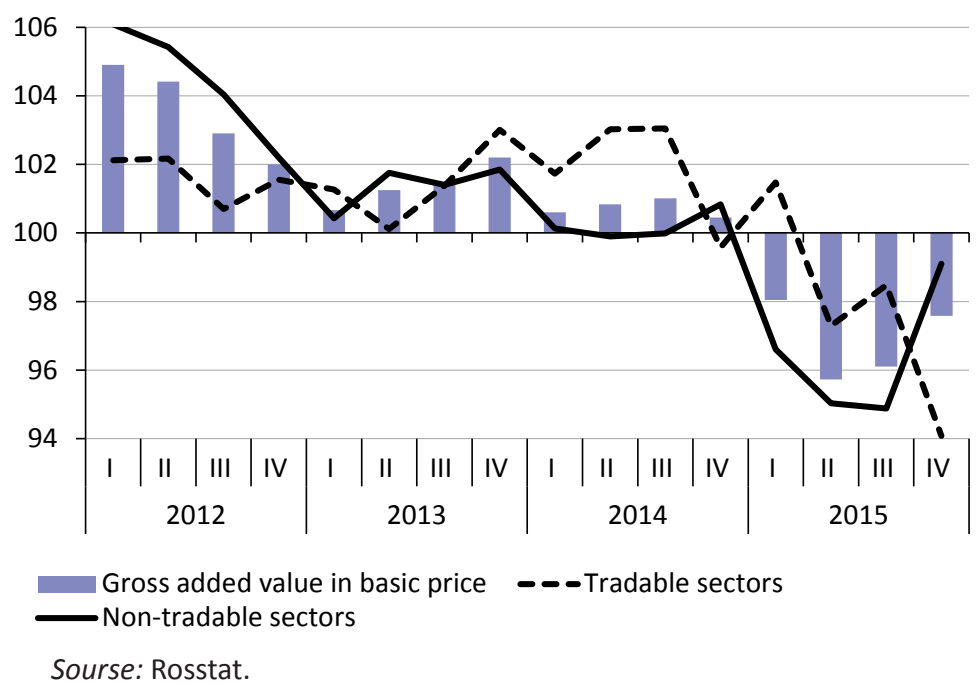

Fig. 3. Movement of GDP across tradable and non-tradable sectors of economy in 2011-2015, \% to corresponding quarter of previous year increased slump in construction and investment activity, contraction of profit generated by operations with real estate. Most significant in 2015 was decrease of rates of wholesale and retail trade as a result of effective demand contraction.

Analysis of dynamic and structure of GDP showed that tradable sectors (extracting, manufacturing and agriculture) remained factor, which stem negative development of events. This is explained by differences in dynamic across types of economic activity. Growth of added value produced in agriculture and extraction of mineral resources in 2015 by $1.8 \%$ compared to the previous year weakened the impact of falling rate of added value production in manufacturing industry by $4.5 \%$. As a result, output in tradable sector of the economy constituted $98.0 \%$ and in non-tradable one $96.3 \%$ against 2014 .

Having reached since H1 2012 pre-crisis level of 2007, the economy began demonstrating signs of slowdown growth. In this context, domestic constraints had a decisive impact. They were due to the fact that the structure of the economy has not evolved significantly and the potential of factors, which accommodate economic growth have been actually exhausted.

In 2015, positive dynamic in the annual terms was registered only in the chemical industry, production of coke and petroleum products and in foodstuffs production.

Prevailing in 2015 trends determined launch conditions for 2016. Slump in manufacturing industry registered in January 2016 came to $5.6 \%$ per annum. As in January 2015, production growth was observed in the food and chemical production. Production of coke and petroleum products contracted by $3.2 \%$ per annum, meanwhile, which was mostly impacted by the fall of crude oil refining by $4.1 \%$ against January 2015 . Amid expected growth of demand on agricultural machines, manufacture of machines and equipment has gone up by $2.2 \%$ per annum. However, taking into consideration last year decline by around $10 \%$ this fact does not change negative prospects of development of this type of activity in the short term. Decline of manufacture of means of transport by $10.7 \%$ per annum has very negatively affected the dynamic of machine building complex. The situation is getting worse due to the current trend manifesting contraction of demand on passenger cars and commercial vehicles. In January 2016, investment in capital assets contracted by $8.4 \%$ 
against last year, volume of works in construction fell by $4.2 \%$ and commission of new housing declined by $12.7 \%$ per annum. However, in short term movement of construction and investment complex is negative because the level of their order books is low, production and import of capital goods is falling, cost of lending facilities is prohibitively high and investment behavior of participants is moderate.

Table 2

\section{PRODUCTION INDICES ACROSS MAIN TYPES OF MANUFACTURING IN 2011-2016, \% TO PREVIOUS PERIOD}

\begin{tabular}{|c|c|c|c|c|c|c|}
\hline & 2011 & 2012 & 2013 & 2014 & 2015 & $\begin{array}{l}\text { January } \\
2016 \text { to } \\
\text { January } \\
2015\end{array}$ \\
\hline Manufacturing & 108.0 & 105.1 & 100.5 & 102.1 & 94.6 & 94.4 \\
\hline $\begin{array}{l}\text { Production of food- } \\
\text { stuffs, including bever- } \\
\text { ages and tobacco }\end{array}$ & 103.9 & 104.1 & 100.6 & 102.5 & 102 & 102 \\
\hline $\begin{array}{l}\text { Textile and gar- } \\
\text { ment manufacture }\end{array}$ & 100.8 & 100.7 & 104.3 & 97.5 & 88.3 & 98.6 \\
\hline $\begin{array}{l}\text { Leather, leather products } \\
\text { and footwear manufacture }\end{array}$ & 105.7 & 98.1 & 95.6 & 97.2 & 88.6 & 99.7 \\
\hline $\begin{array}{l}\text { Wood processing and } \\
\text { woodwork production }\end{array}$ & 110.2 & 96.2 & 108.0 & 94.7 & 96.6 & 96.0 \\
\hline $\begin{array}{l}\text { Paper production; publish- } \\
\text { ing and printing activity }\end{array}$ & 106.5 & 105.8 & 94.8 & 100.4 & 93.7 & 98.4 \\
\hline $\begin{array}{l}\text { Production of coke and } \\
\text { petroleum products }\end{array}$ & 103.8 & 103.1 & 102.3 & 105.7 & 100.3 & 96.8 \\
\hline Chemical production & 109.5 & 104.1 & 105.4 & 100.1 & 106.3 & 103.9 \\
\hline $\begin{array}{l}\text { Production of rubber } \\
\text { and plastic articles }\end{array}$ & 111.4 & 112.8 & 105.9 & 107.5 & 96.3 & 97.3 \\
\hline $\begin{array}{l}\text { Production of other non- } \\
\text { metallic mineral goods }\end{array}$ & 107.4 & 110.7 & 98.0 & 101.8 & 92.2 & 82.8 \\
\hline $\begin{array}{l}\text { Metallurgy and manu- } \\
\text { facture of finished } \\
\text { metal products }\end{array}$ & 107.0 & 104.8 & 100.0 & 100.6 & 93.5 & 93.5 \\
\hline $\begin{array}{l}\text { Manufacture of machines } \\
\text { and equipment }\end{array}$ & 111.1 & 102.7 & 96.6 & 92.2 & 88.9 & 102.2 \\
\hline $\begin{array}{l}\text { Manufacture of elec- } \\
\text { tric, electronic and } \\
\text { optic equipment }\end{array}$ & 111.9 & 106.4 & 99.0 & 99.5 & 92.1 & 97.5 \\
\hline $\begin{array}{l}\text { Manufacture of means of } \\
\text { transport and equipment }\end{array}$ & 117.2 & 110.3 & 102.2 & 108.5 & 91.5 & 89.3 \\
\hline Other production works & 105.3 & 102.6 & 95.4 & 102.7 & 94.0 & 87.8 \\
\hline
\end{tabular}

Source: Rosstat.

In case of deterioration of economic movement, population trying to minimize risks rather calmly treated purchase of many goods and services. Reduction of real income, increased burden on households regarding loans service payments and growth of inflationary expectations in January 2016 resulted in contraction of retail trade turnover by $7.3 \%$ and paid services to population by $2.7 \%$ per annum. Contraction of consumer demand was accompanied by shrinkage of market of food and non-food products. In January 2016, the food market constituted $93.7 \%$ and non-food products 91.8\% against January 2015 indices. 
Labor remuneration significantly affects the level of income of population (66.0\% in income of population) and manifested by the year-end trend to further reduction of real wages becomes major factor, which determines social parameters of the living standard of the population in 2016. In January 2016 , real income of the population came to $93.7 \%$ and real wages $-93.9 \%$ of January 2014 indices.

Changes on the labor market are conditioned by growing total and registered unemployment. In January 2016, the number of unemployed (according to WLO methodology) was estimated at 4,428,000 persons, and the level of unemployment came to $5.8 \%$ of economically active population, which is up 0.6 p.p. against similar indicator last year. Total number of jobless 4.4 times exceeded the number of jobless registered in state employment agencies. In January 2016, the state employment agencies registered 1,017,000 jobless up $10.1 \%$ compared to January 2015 . Labor market adjustment is unfolding with the use of traditional schemes of part-time employment, giving an unpaid leave, which allows to keep qualifies staff in expectation of production growth recovery and also lift social tension. Feasibility of employment growth and labor costs are rigorously constrained due to changes in competition environment and outcome of financial activity of enterprises and organizations.

Development of the Russian economy reflects a falling development potential. This is confirmed by high capacity utilization, lack of large-scale investment and low level of unemployment. According to projections, in H1 2016 the situation will be defined by the downward trend in the industrial development amid deepening contraction of manufacturing output ${ }^{1}$. Projected contraction of investment for 2016 in capital assets by $7.0 \%$, in the retail trade turnover by $7.0 \%$ will determine further shrinkage of domestic demand.

1 Monthly bulletin "Model calculations of short-run forecasts of Russian economic time series" (http://www.iep.ru/ru/ob-izdanii.html). February 2016. 